\title{
Influence of Perkinsus Infection on the Physiology and Behavior of Adult Manila Clam Ruditapes philippinarum
}

\author{
Tomoyoshi Yoshinaga*, Shinji Watanabe, Tsukasa Waki, Shigeru Aoki and Kazuo Ogawa \\ Graduate School of Agricultural and Life Sciences, The University of Tokyo, Tokyo 113-8657, Japan
}

(Received September 14, 2009)

\begin{abstract}
Annual catch landings of the Manila clam Ruditapes philippinarum have decreased in Japan since the early 1980 s because of the decreased size of many Manila clam populations. It is hypothesized that Perkinsus olseni infection contributed to these decreases. However, the effect of Perkinsus infection on the survival and physiology of Manila clam is poorly understood. We examined the influence of Perkinsus infection on clearance rate, tolerance against high water temperature, and burrowing activity in a captive adult clam population. Infection intensity did not affect clearance rates, burrowing activity, or tolerance against high water temperature. In addition, we monitored infection intensity in wild, adult clams from a tidal flat lacated in western Seto Inland Sea over a one-year period. Infection levels were relatively stable in the wild population between June 2004 and May 2005, but we noted a significant decrease in the infection intensity at the end of the spawning period in November 2004. However, in the present study, clear evidence showing the negative impact of Perkinsus on clam physiology and survival was not obtained.
\end{abstract}

Key words: Perkinsus olseni, Perkinsus honshuensis, Ruditapes philippinarum, Manila clam, survival, tolerance, burrowing activity, clearance rate

Manila clams are an important shellfish resource for local fisheries and public recreation in Japan. However, there have been appreciable declines in annual catch landings since the early 1980s because of the decreased size of many Manila clam populations (Matsukawa et al., 2008). These decreases have been attributed to a number of factors, including changes in substrate quality due to fishing activity, decreases in the influx of sand and water in association with dam construction, changes in climate, the inflow of chemical pollutants, and increases in the number of predators and competitors (Matsukawa et al., 2008). In addition, Hamaguchi et al. (1998) and Park and Choi (2001) suggested that the protozoan parasite Perkinsus olseni (formerly Perkinsus atlanticus) is a contributing factor to the decline in Japanese and Korean populations of Manila clam. Hamaguchi et al. (2002) demonstrated that most Manila clam populations in Japan other than those in northern and eastern Hokkaido were infected with $P$. olseni. However, their suggestion was refuted by Momoyama and Taga (2005) based on their monitoring of infection levels and the condition of clams from a tidal flat in the Yamaguchi Prefecture, western Seto Inland Sea, an area that had experienced the biggest decline in annual landings.

\footnotetext{
* Corresponding author

E-mail: atyoshi@mail.ecc.u-tokyo.ac.jp
}

P. Olseni infections have been documented in Manila clams, carpet-shell clams Ruditapes decussates, abalones Haliotis spp., and several other bivalve and gastropod species in East and Southeast Asia, Europe, Australia, and New Zealand (Ciggaría et al., 1997; Hamaguchi et al., 1998; Maeno et al., 1999; Park et al., 1999; Lee et al., 2001; Liang et al., 2001; Park and Choi, 2001; Choi et al., 2002; Momoyama and Taga, 2005; Sakai and Onodera, 2006; Elandaloussi et al., 2008; Park et al., 2008). Recently, Dungan and Reece (2006) reported that Manila clams from a population in Japan were infected with both $P$. olseni and $P$. honshuensis, the latter of which was described as a new species in their study. Similarly, Takahashi et al. (2009) found both $P$. olseni and $P$. honshuensis in Manila clams from the western Seto Inland Sea, the area from which we obtained sample clams for the present study. Despite these studies, the distribution of $P$. honshuensis remains poorly understood.

Our objective was to determine the effect of Perkinsus infection on Manila clam. We evaluated the relationship between Perkinsus infection intensity and several physiological/behavioral traits. We also measured Perkinsus infection intensity in Manila clams that were collected throughout the year from a tidal flat where heavy infection with Perkinsus was found in Manila clams. 


\section{Materials and Methods}

Influence of Perkinsus infection on the physiology and behavior of Manila clam

We evaluated the relationship between infection intensity and several indicators of health and activity, including the clearance rate, burrowing activity, and tolerance to high water temperature, in Manila clams that were purchased from a local clam farm in Ohno (Fig. 1, Location A) $(34.28 \mathrm{~N}, 132.27 \mathrm{E})$. We measured the clearance rate and tolerance to high water temperature at the Fisheries Laboratory, University of Tokyo, Shizuoka Prefecture, and the burrowing activity at Hongo Campus, University of Tokyo, Tokyo, Japan.

We measured the clearance rate by using the indirect method in October 2005. The clams $(N=30$; shell length [SL], 33-44 $\mathrm{mm}$ ) were acclimated in running seawater at $20^{\circ} \mathrm{C}$ for $24 \mathrm{~h}$ before the experiment. The clams were then placed individually in a chamber containing $500 \mathrm{~mL}$ of seawater and were fed continuously with a commercially available diatom solution (Chaetoceros calcitrans: $6.3 \times 10^{4}-2.9 \times 10^{5}$ cells $/ \mathrm{mL}$; Sunculture, Nisshin Marintech) by using a peristaltic pump. We measured the diatom density in the inflow $\left(\mathrm{C}_{\text {in }}\right.$ cells $\left./ \mathrm{mL}\right)$ and outflow $\left(\mathrm{C}_{\text {out }}\right.$ cells $\left./ \mathrm{mL}\right)$ by using a hemocyte counting chamber. The flow rate (Fr: $\mathrm{mL} / \mathrm{min}$ ) was adjusted between 440 and $900 \mathrm{~mL} / \mathrm{h}$ to maintain $\mathrm{C}_{\text {out }}$ between $10^{4}$ and $10^{5}$ cells $/ \mathrm{mL}$. We calculated the clearance rate $(\mathrm{Cr})$ by using the following formula: $\mathrm{Cr}(\mathrm{mL} / \mathrm{min})=\mathrm{Fr} \times\left(\mathrm{C}_{\text {in }}-\mathrm{C}_{\text {out }}\right) / \mathrm{C}_{\text {in }}$.

The clearance rate stabilized within $2 \mathrm{~h}$ of transferring the clams into the chambers. Therefore, $\mathrm{C}_{\text {out }}$ and $\mathrm{C}_{\text {in }}$ were measured five times every hour beginning $2 \mathrm{~h}$ after the transfer. We quantified the infection intensity in the outermost gill leaf at the end of the experiment. For quantification of the intensity of Perkinsus infection, conventional Ray's fluid thioglycollate medium (FTM) was used throughout this study, following the methods

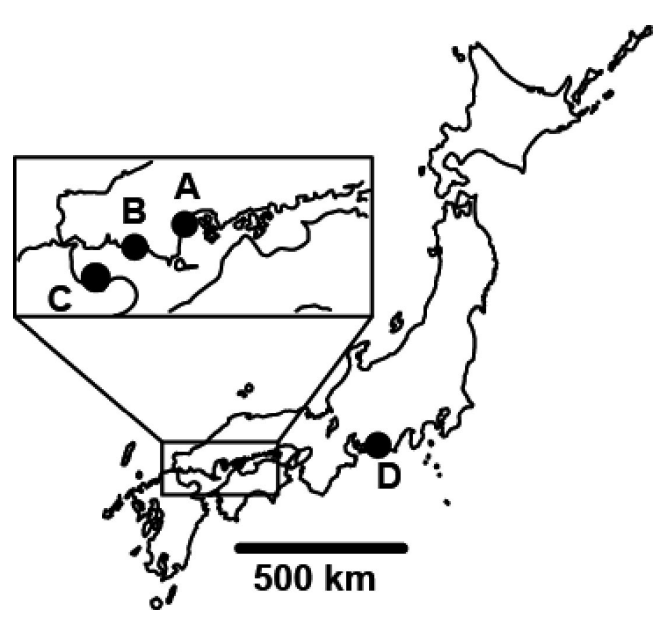

Fig. 1. Location of sampling sites. A: Ohno, B: Tokuyama, C: Oita, and D: Lake Hamana. of Choi et al. (1989) and Almeida et al. (1999). Briefly, the outermost left or right gill leaf was removed from each clam, excess water was removed with filter paper, and the tissue was weighed. We then incubated the gill tissue in Ray's FTM at $25^{\circ} \mathrm{C}$ for one week. Following incubation, the gill tissue was lysed in $2 \mathrm{~N} \mathrm{NaOH}$ at $60^{\circ} \mathrm{C}$, washed three times in phosphate-buffered saline (PBS), and centrifuged $(1,600 \times g, 15 \mathrm{~min})$. The resulting pellet was suspended in $1 \mathrm{~mL}$ PBS, $10 \mu \mathrm{L}$ of the resuspension was placed in each well of a 96-well plate, and the number of prezoosporangia was counted in $10-\mu \mathrm{L}$ aliquots under an inverted microscope. The sensitivity of detection was approximately $10^{3}$ cells $/ g$ of gill tissue.

To evaluate the effect of infection on temperature tolerance, we collected heavily infected clams (SL, 34-43 $\mathrm{mm}$ ) and moderately infected clams (SL, 34-50 $\mathrm{mm}$ ) from the clam farm in Ohno and from Lake Hamana (Location D) (34.70N, 137.60E), respectively. We quantified the initial infection intensity in 30 individual clams from each group using Ray's FTM. The clams from each group ( $N=76$ per group) were placed in separate baskets in a $40-\mathrm{L}$ aquarium. The aquarium was supplied with temperature-controlled seawater. We gradually increased the water temperature from $22^{\circ} \mathrm{C}$ to $28^{\circ} \mathrm{C}$ over $4 \mathrm{~d}$ and maintained the temperature at $28^{\circ} \mathrm{C}$ for $8 \mathrm{~d}$. We counted the number of live clams twice a day and moribund or dead clams were removed from the aquarium. We measured the final infection intensity in the outermost gill leaf at the conclusion of the experiment.

We measured burrowing activity in clams (SL, $32-43 \mathrm{~mm})(\mathrm{N}=30)$ that were obtained from the clam farm in Ohno in August 2005. The clams were acclimated at $20^{\circ} \mathrm{C}$ for one week and fed a diatom suspension before the experiment. Each clam was placed in a 1-L aquarium containing quartzose sand, and the aquarium was subsequently placed on the bottom of a $100-\mathrm{L}$ recirculating aquarium $\left(20^{\circ} \mathrm{C}\right)$. We observed the burrowing behavior of each individual continuously for 2 h, every $30 \mathrm{~min}$ for the next $4 \mathrm{~h}$, and once at $24 \mathrm{~h}$. We recorded the time taken for each clamshell to disappear under the sand. After the experiment, we measured the infection intensity in the outermost gill leaf using Ray's FTM.

\section{Field survey}

We collected Manila clams (SL, 30-40 mm) each month ( $N=30$ per month) between June 2004 and May 2005 from a tidal flat near Tokuyama, Yamaguchi Prefecture, western Seto Inland Sea (34.03N, 131.82E) (Fig. 2, Location B). This area has shown one of the most drastic decreases in annual landings; annual landings decreased from 8,000 to several metric tons in the coast of Seto Inland Sea in Yamaguchi Prefecture since the early 1980s. No Manila clams were released for 

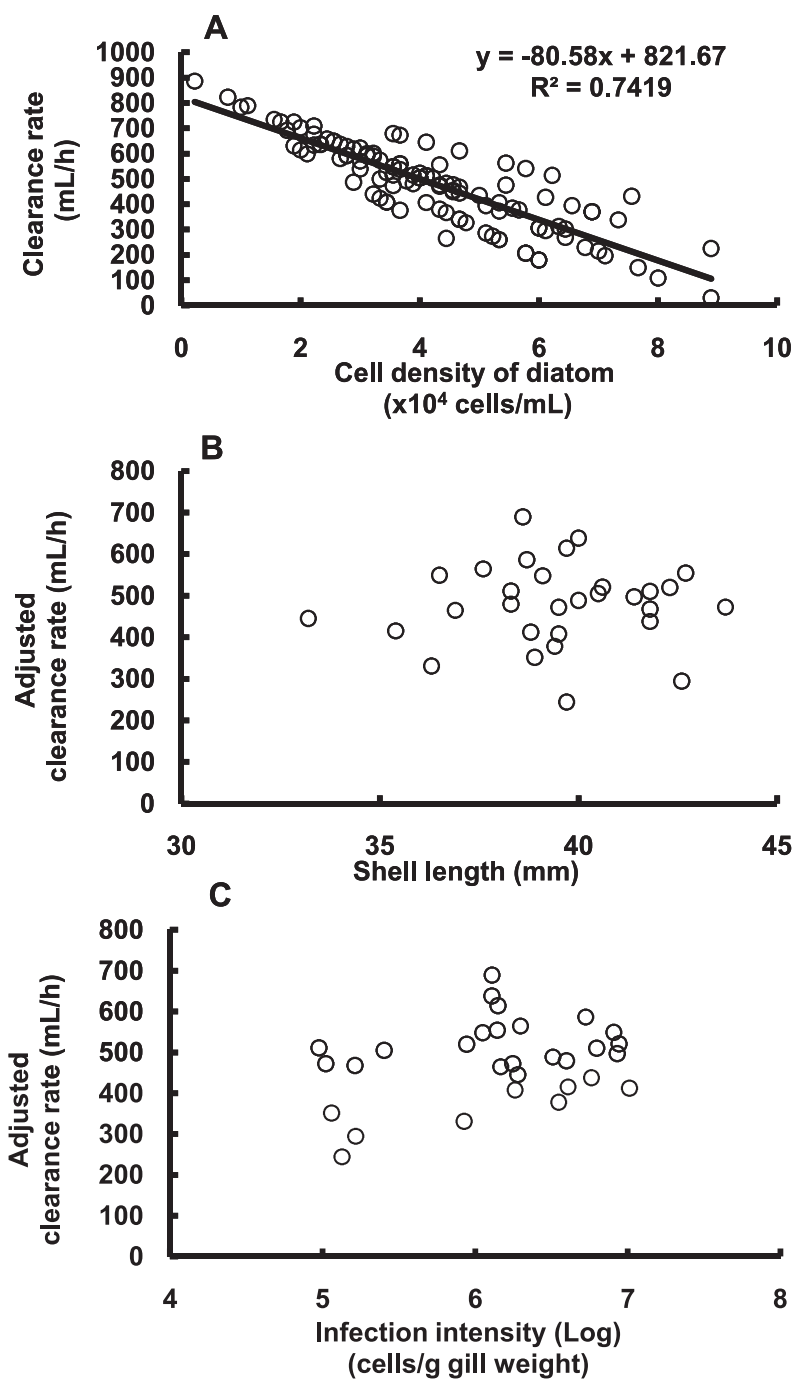

Fig. 2. Clearance rates in Manila clams infected with Perkinsus species. A: Relationship between diatom cell density and clearance rate. B: Relationship between shell length and adjusted clearance rate. C: Relationship between infection intensity and adjusted clearance rate.

stock enhancement in the flat during the field survey and all Manila clams collected were wild.

We measured SL $(\mathrm{mm})$, shell height $(\mathrm{SH})(\mathrm{mm})$, and shell width (SW) $(\mathrm{mm})$ before removal of soft tissue. The animals were placed on filter paper to remove excess fluid and the soft tissue weight (STW) (mg) was measured. We calculated a condition index $(\mathrm{Cl})$ by using the following formula: STW $/(\mathrm{SL} \times \mathrm{SH} \times \mathrm{SW}) \times$ 1,000 .

Following removal of one gill leaf for quantification of infection intensity, the remaining soft tissue was cut transversally into anterior and posterior sections. The posterior section was impregnated on a glass slide, and the anterior section was fixed in $10 \%$ buffered formalin for histological examination. The impregnated tissue preparations were stained using a commercial cytostain- ing kit (Diff-Quick staining; Sysmex International Reagents Co. Ltd.). For histological examination, a tissue slice of approximately 5-mm thickness was excised from each of the fixed tissues, embedded in paraffin, sectioned at $5 \mu \mathrm{m}$, and stained using hematoxylin and eosin. We examined the impregnated preparations and histological sections microscopically to find trematode sporocysts and to determine the stage of sexual development in each clam, respectively. Sexual development was categorized into five stages: undifferentiated, developing, ripe, spawning, and spent.

\section{Statistical analyses}

We tested for differences between two groups using the Mann-Whitney $U$ test. We evaluated the differences among more than three groups using the Kruskal-Wallis test followed by the Steel-Dwass test. The statistical test used for each analysis is stated in the Results section. We used Kendall's rank test to evaluate the correlation between infection intensity and physiology, morphology, or behavior. We used the Chi-square test to evaluate differences in survival of Manila clams. For all analyses, a $p$ value of $<0.05$ was considered significant.

\section{Results}

Effect of Perkinsus infection on the physiology and behavior of Manila clams

Clearance rate: The initial level of Perkinsus infection was high (prevalence: $100 \%$; mean infection intensity, $5 \times 10^{6}$ cells/g gill tissue). Furthermore, the clams were likely infected with both $P$. olseni and $P$. honshuensis (Takahashi et al., 2009). We observed a significant correlation between clearance rate and diatom density $\left(\mathrm{CR}=-80.6 \times 10^{-4} \times \mathrm{C}_{\text {out }}+821.7\right)($ Fig. $2 \mathrm{~A})$. Accordingly, we adjusted the clearance rates by using the following formula: adjusted $\mathrm{CR}=-80.6 \times\left(5 \times 10^{4}-\mathrm{C}_{\text {out }}\right)+$ CR. The adjusted CR represents the expected clearance rate, assuming that the clams were maintained in a suspension containing $5 \times 10^{4}$ diatom cells $/ \mathrm{mL}$. We found no relationship between the mean adjusted clearance rate and SL or infection intensity (Kendall's rank test) (Fig. 2B and C).

Temperature tolerance: We observed a large difference in the prevalence and infection intensity in the two groups of Manila clams that were used for the temperature tolerance test. The original prevalences and geometric mean infection intensities before the experiment were $100 \%$ and $4.4 \times 10^{6}$ cells/g gill tissue and $76.7 \%$ and $4.4 \times 10^{4}$ cells $/ g$ gill tissue for the clams from the Seto Inland Sea and Lake Hamana, respectively, and the mean intensity was significantly different (MannWhitney $U$ test). There was no difference in the mean $\mathrm{SL}$ of the two groups (38 $\mathrm{mm}$ and $41 \mathrm{~mm}$, respectively) (Mann-Whitney $U$ test). Similarly, there was no differ- 


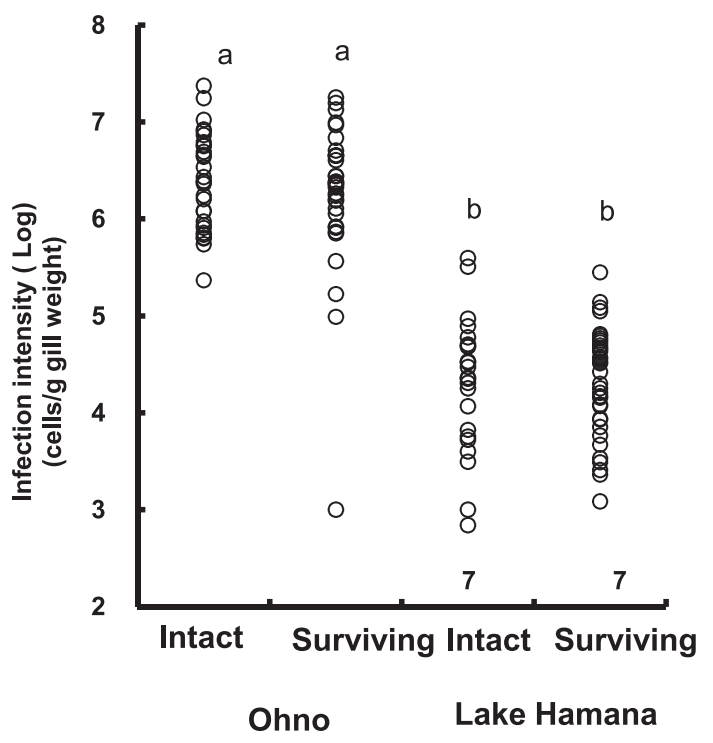

Fig. 3. Infection intensities in intact Manila clams before high water temperature treatment and in clams that survived high water temperature treatment. We used two clam groups that had different levels of initial infection. The numerals on the $x$-axis represent the number of clams that had an infection intensity below the detectable level. Different letters represent significant differences (Kruskal-Wallis test followed by SteelDwass test).

ence in the level of mortality between the two groups after exposure to high temperature (Chi-square test). In total, $58 \%(\mathrm{~N}=44)$ of the clams from the Seto Inland Sea and $45 \%(N=34)$ of the clams from Lake Hamana died during the experiment. Despite the high mortalities in both groups, there was no significant difference in the infection intensity between the clams before and after exposure to high temperature in both clam groups obtained from the Seto Inland Sea and Lake Hamana (Steel-Dwass test) (Fig. 3).

Burrowing activity: We observed ten clams burrowing during the first $2 \mathrm{~h}$ and nine clams during the last 18 $\mathrm{h}$ of the experiment. There was no significant correlation between infection intensity and the time taken to burrow in the ten clams that burrowed within $2 \mathrm{~h}$ (Kendall's rank test) (Fig. 4A). Similarly, there was no significant difference in the level of infection among clams that burrowed within $2 \mathrm{~h}$, between 6 and $24 \mathrm{~h}$, or those that did not burrow (Steel-Dwass test) (Fig. 4B).

\section{Field survey}

Water temperature fluctuated seasonally at the collection site. The temperatures were constantly above $25^{\circ} \mathrm{C}$ during the summer and decreased to approximately $10^{\circ} \mathrm{C}$ in winter (Fig. $5 \mathrm{~A}$ ). SL varied throughout the year, although there was no clear seasonal pattern (Steel-Dwass test) (Fig. 5B). In contrast, the mean $\mathrm{Cl}$ varied significantly among the months. The mean $\mathrm{Cl}$ declined significantly between September and November
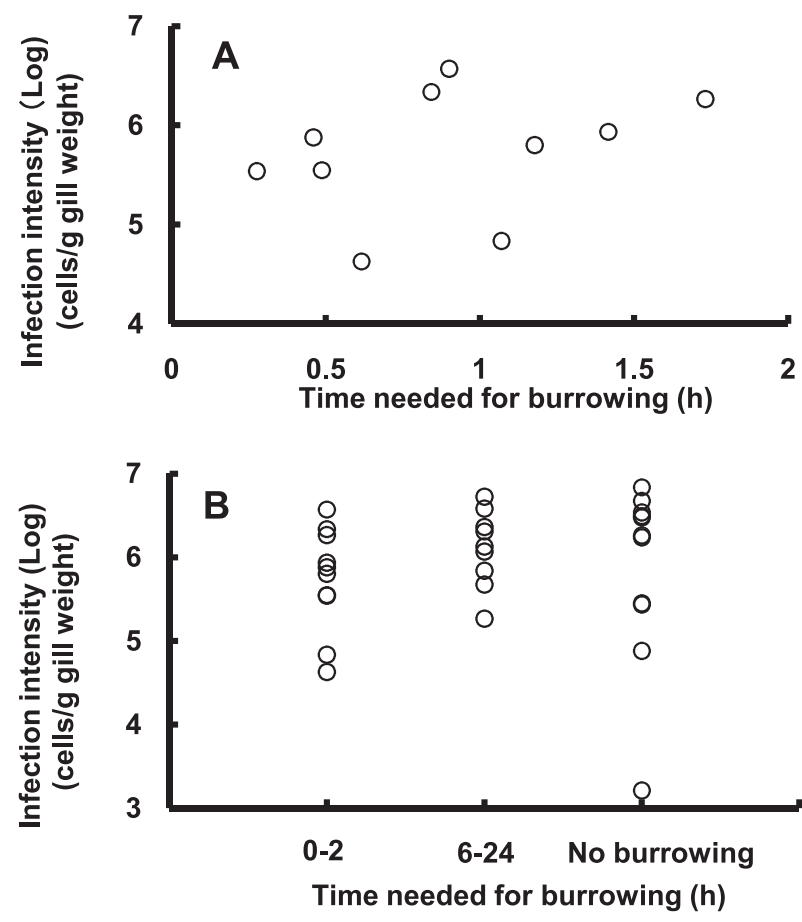

Fig. 4. Relationship between infection intensity and time taken to burrow. A: The time taken to burrow was plotted against infection intensity for clams that completed burrowing within $2 \mathrm{~h}$ after the beginning of the experiment. B: The clams were categorized into those that burrowed within the first $2 \mathrm{~h}$, those that burrowed between 6 and $24 \mathrm{~h}$ after the experiment began, and those that did not burrow within $24 \mathrm{~h}$.

and increased between January and April (Steel-Dwass test) (Fig. 5C). Furthermore, there was a significant decline in the $\mathrm{Cl}$ between April and May (Steel-Dwass test).

Although the maturation level of ten clams infected with trematode sporocysts was not clear, we noted a clear seasonal pattern of sexual maturation in other clams uninfected with trematode. Ripe clams were observed between June and November and April and May, but generally not between December and March (Fig. 5D).

In contrast, we detected Perkinsus infection in 99.4\% of clams ( $N=358$ ) (Fig. 5E). The infection intensity ranged between $10^{4}$ and $10^{7}$ cells/g gill tissue. The geometric mean infection intensity was approximately $10^{6}$ cells/g gill tissue between August and October and December and April. Interestingly, the geometric mean infection intensity in November was approximately one-tenth of the average annual intensity and was significantly lower than the other months (SteelDwass test) (Fig. 5E). Subsequently, the intensity rapidly recovered in December. The infection intensity decreased slightly, but not significantly, between April and May (Fig. 5E), which was accompanied by a slight decrease in mean $\mathrm{Cl}$. The clams that were infected 
A: water temperature
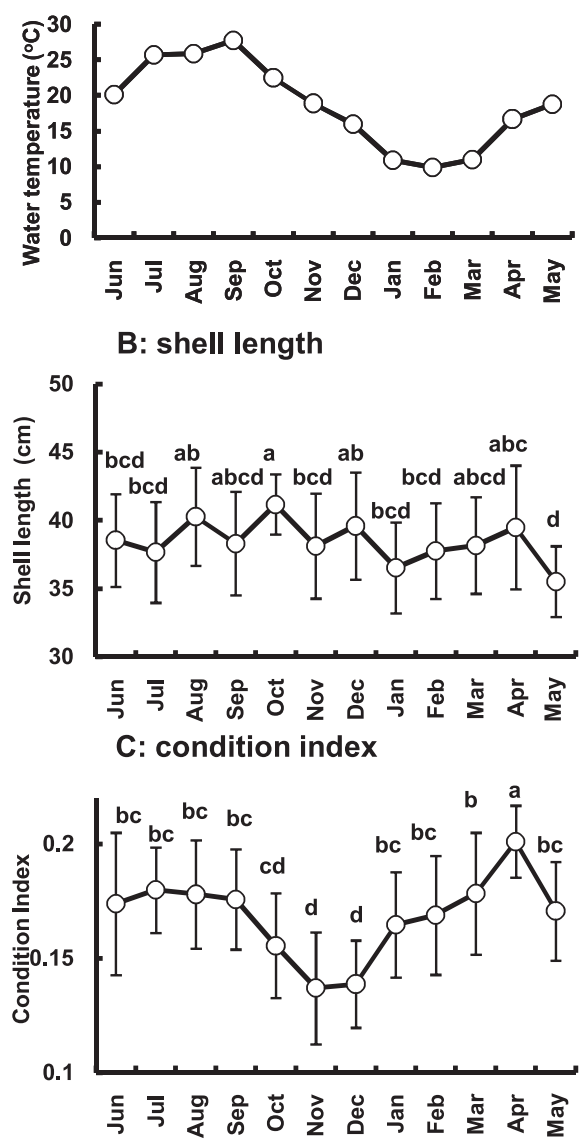

\section{D: maturation}

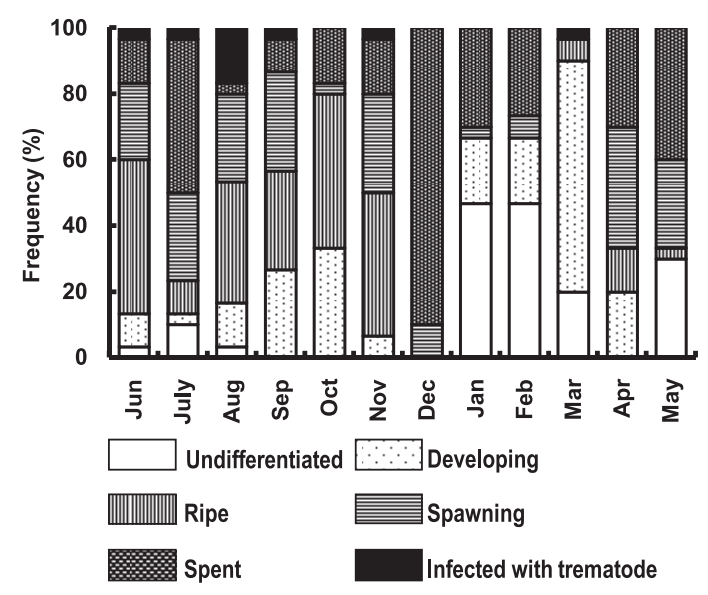

E: infection intensity with Perkinsus

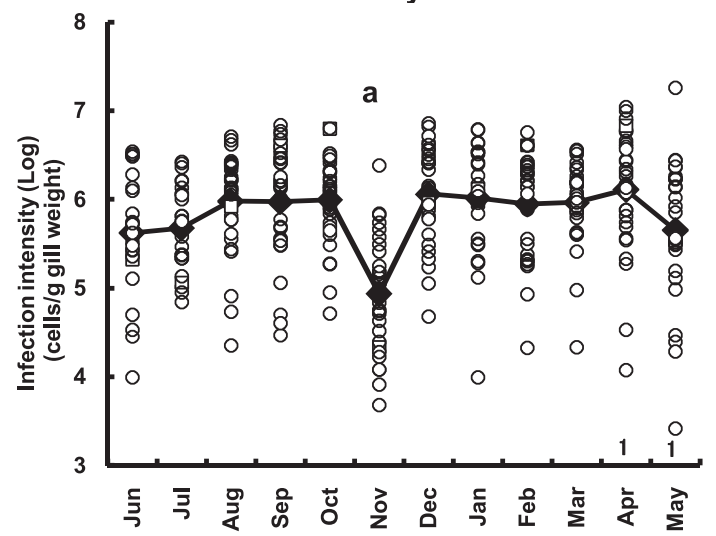

Fig. 5. Water temperature (A), shell length (B), condition index (C), maturation (D), and intensity of Perkinsus infection (E) in Manila clams sampled from a tidal flat in the western Seto Inland Sea between June 2004 and May 2005 . The values for B and C represent the mean and standard deviation. Infection intensities for all clams (open circle) and the mean values (closed diamonds with solid line) are shown in E. Data from clams infected with trematode sporocysts were omitted from the calculation of condition index in $\mathrm{C}$. Numerals on the $\mathrm{x}$-axis in $\mathrm{E}$ represent the number of clams that had infections below the detectable level (approximately $10^{3}$ cells/g gill weight). Different letters represent significant differences in C, D, and E (Kruskal-Wallis test followed by Steel-Dwass test).

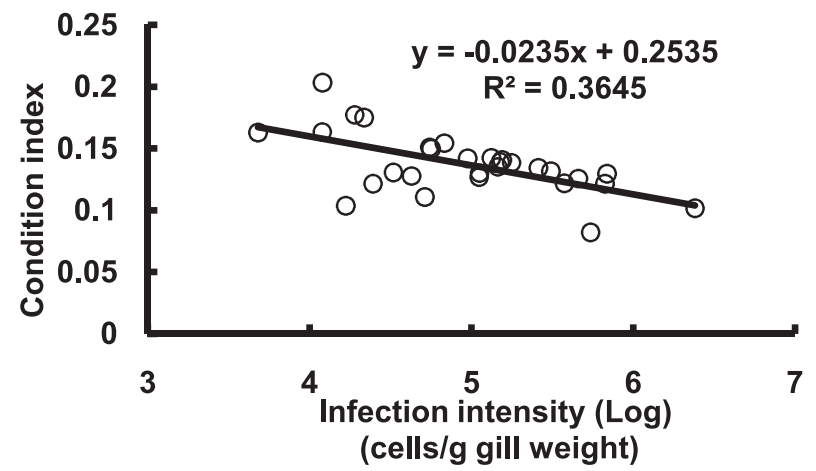

Fig. 6. Correlation between the infection intensity and condition index in Manila clams sampled in November. A significant negative correlation was detected (Kendall's rank test, $p<0.05$ ).

with trematode sporocysts were omitted from the analysis of the relationship between infection intensity and $\mathrm{Cl}$. We observed a significant inverse relationship between these two variables in November only, whereas no significant relationships were detected in the other months (Kendall's rank test) (Fig. 6).

\section{Discussion}

We carried out the present study before the discovery of Perkinsus honshuensis in Japan; therefore, we did not consider the possibility that these clams were coinfected with $P$. olseni and $P$. honshuensis. However, we recently found both $P$. olseni and $P$. honshuensis in clams in the clam farm in Ohno and a tidal flat in Oita Prefecture (Location C in Fig. 1) (33.37N, 131.11E), both of which are located in the western Seto Inland Sea (Takahashi et al., 2009). It is possible that the clams collected for the experiments and survey were infected with both Perkinsus species.

In the present study, Perkinsus infection showed no influence on temperature tolerance, burrowing activi- 
ty, or clearance rates in Manila clams. The results suggest that Perkinsus infection has little impact on adult clams with $\mathrm{SL}>30 \mathrm{~mm}$.

During the one-year field survey, we noted that the Perkinsus infection levels were significantly lower in November than in any other months, although it is unclear whether this seasonal pattern is stable between years. Previous studies suggest that the pattern of seasonal changes in Perkinsus sp. infection in clams varies with the geographic locations and the host species of clams. For example, Perkinsus infection was less prevalent during winter in the carpet-shell clam from Spain than during other seasons (Villalba et al., 2005). Conversely, the intensity of $P$. olseni infection peaked in October in Manila clams from Korea (Park et al., 2006). Ngo and Choi (2004) reported that the infection incidence varied dramatically from $6 \%$ in March to $86 \%$ in September in a population of Manila clams from the coast of Jeju Island, Korea. Similarly, in Manila clams and carpet-shell clams from the Ebro Delta, Spain, the infection prevalence ranged from $20 \%$ to $100 \%$ (mean prevalence: $71 \%$ and $79 \%$, respectively) and was not obviously seasonal (Elandaloussi et al., 2008). Leite et al. (2004) documented P. olseni infections in carpet-shell clams from a variety of locations along the Portuguese coast over a two-year period. The authors noted that $P$. olseni infections varied seasonally at some locations, but the pattern was not similar among the locations. Taken together with these previous reports, the present results indicate that many factors, including infection levels, environmental conditions, clam density, and host species affect the seasonality of $P$. olseni infections.

The end of the spawning season (November and December) coincided with the lowest mean $\mathrm{Cl}$ and the lowest infection intensity. We hypothesize that the decrease in $\mathrm{Cl}$ was caused by exhaustion because of the long spawning period. Given that many of the animals were in poor condition, it is possible that the heavily infected clams died during the season, leaving the less infected clams. The correlation between infection intensity and $\mathrm{Cl}$ in November suggests that Perkinsus infection had a negative influence on clam physiology in this month. On the other hand, the infection intensity rapidly recovered in December, when the $\mathrm{Cl}$ remained as low as in November. We do not have an explanation for the recovery of the infection intensity in December. The observations from our survey are not enough to prove the pathogenicity of Perkinsus on clams. However, our study appears to have two valuable observations: First, monitoring was carried out over one year in a heavily infected clam population that had a prevalence of nearly $100 \%$ and geometric mean infection intensity as high as $10^{6} \mathrm{cells} / \mathrm{g}$ gill tissue weight. Second, the area from which we collected the clams experienced the largest decline in annual landings of
Manila clams in Japan. The present observations will be helpful for our future discussion on the impact of Perkinsus infection on Manila clam populations, although we are currently not able to draw a clear conclusion from them.

A number of studies have evaluated the impact of $P$. marinus on the physiology of the Eastern oyster, Crassostrea virginica (reviewed by Villalba et al., 2004). However, our knowledge is very limited regarding the impact of the closely related $P$. olseni on the physiology of Manila clams. Park et al. (2006) found a negative correlation between gonadosomatic index and infection intensity in Manila clams from Gomso Bay, Korea, suggesting that high levels of infection with $P$. olseni have a long-term effect on growth, reproduction, gonad maturation, and egg production. Villalba et al. (2005) noted higher mortality in an infected population of carpet-shell clams relative to an uninfected population, suggesting that infections may play a role in regulating population size. Recently, we experimentally demonstrated that $P$. olseni caused direct mortalities in juvenile Manila clams with an infection intensity of about $10^{7}$ pathogens cells/g soft tissue (Shimokawa et al., 2010). However, little is known regarding the infection intensity of Perkinsus species in juvenile Manila clams in natural environments. Further studies are needed to evaluate the impact of Perkinsus infection on Manila clams.

\section{Acknowledgments}

The authors thank Dr. Kazuo Momoyama (Yamaguchi Prefectural Fisheries Research Center) for help in collecting adult clams during the field survey. This research was partially supported by the Ministry of Education, Science, Sports and Culture, Grant-in Aid for challenging Exploratory Research (21658069).

\section{References}

Almeida, M., F. Berthe, A. Thébault and M. T. Dinis (1999): Whole clam culture as a quantitative diagnostic procedure of Perkinsus atlanticus (Apicomplexa, Perkinsea) in clams Ruditapes decussates. Aquaculture, 177, 325-332.

Choi, K. S., K. I. Park, K. W. Lee and K. Matsuoka (2002): Infection intensity, prevalence and histology of Perkinsus sp. in the Manila clam, Ruditapes philippinarum, in Isahaya Bay, Japan. J. Shellfish Res., 21, 119-125.

Choi, K. S., E. A. Wilson, D. H. Lewis, E. N. Powell and S. M. Ray (1989): The energetic cost of Perkinsus marinus parasitism in oysters: quantification of the thioglycollate method. J. Shellfish Res., 8, 125-131.

Ciggaría, J., C. Rodríguez and J. M. Fernandes (1997): Impact of Perkinsus sp. on Manila clam Ruditapes philippinarum beds. Dis. Aquat. Org., 29, 117-120.

Dungan, C. F. and K. C. Reece (2006): In vitro propagation of two Perkinsus spp. parasites from Japanese Manila clams Venerupis philippinarum and description of Perkinsus honshuensis n. sp. J. Eukaryot. Mircobiol., 53, 316-326.

Elandaloussi, L. M., N. Carrasco, A. Roque, M. Fernandez- 
Tejedor and D. Furones (2008): Occurrence of Perkinsus $\mathrm{sp}$. in two clam species (Ruditapes philippinarum and $R$. decussatus) from the Ebro Delta, Spain. Bull. Eur. Assoc. Fish Pathol., 28, 1-9.

Hamaguchi, M., N. Suzuki, H. Usuki and H. Ishioka (1998): Perkinsus protozoan infection in short-necked clam Tapes (= Ruditapes) philippinarum in Japan. Fish Pathol., 33, 473-480.

Hamaguchi, M., M. Sasaki, and H. Usuki (2002): Prevalence of a Perkinsus protozoan in the clam Ruditapes philippinarum in Japan. Jpn. J. Benthol., 57, 168-176. (In Japanese)

Lee, M., B. Y. Cho, S. J. Lee, J. Y. Kang, H. D. Jeong, S. H. Huh and M. D. Huh (2001): Histopathological lesions of Manila clam, Tapes philippinarum, from Hadong and Namhae coastal areas of Korea. Aquaculture, 201, 199-209.

Leite, R. B., R. Afonso and Cancela M. L. (2004): Perkinsus sp. infestation in carpet-shell clams, Ruditapes decussatus $(\mathrm{L})$, along the Portuguese coast. Results from a 2-year survey. Aquaculture, 240, 39-54.

Liang Y. B., X. C. Zhang, L. J. Wang, B. Yang, Y. Zhang and C. L. Cai (2001): Prevalence of Perkinsus sp. in the Manila clam, Ruditapes philippinarum, along the Northern coast of the Yellow Sea in China. Oceanol. Limnol. Sinica, 32, 502-511.

Maeno, Y., T. Yoshinaga and K. Nakajima (1999): Occurrence of Perkinsus species (Protozoa, Apicomplexa) from manila clam Tapes philippinarum in Japan. Fish Pathol., 34, 127-131.

Matsukawa, Y., N. Cho, S. Katayama and K. Kamio (2008): Factors responsible for the drastic catch decline of the Manila clam Ruditapes philippinarum in Japan. Nippon Suisan Gakkaishi, 74, 137-143.

Momoyama, K. and S. Taga (2005): Detection of a parasitic protozoa Perkinsus sp. in the clam Ruditapes philippinarum collected from the tidal flats along the Seto Inland Sea in Yamaguchi Prefecture. Bull. Yamaguchi Pref. Fish. Res. Cent., 3, 111-117. (In Japanese)

Ngo, T. T. T. and K. S. Choi (2004): Seasonal changes of Perkinsus and Cercaria infections in the Manila clam Ruditapes philippinarum from Jeju, Korea. Aquaculture,
239, 57-68.

Park, K. I. and K. S. Choi (2001): Spatial distribution of the protozoan Perkinsus sp. found in the Manila clams, Ruditapes philippinarum, in Korea. Aquaculture, 203, 9-22.

Park, K. I., K. I. Choi and J. W. Choi (1999): Epizootiology of Perkinsus sp. found in the Manila clam, Ruditapes philippinarum, in Komsoe Bay, Korea. J. Korean Fish. Sci., 32, 303-309. (In Korean)

Park, K. I., A. Figueras and K. I. Choi (2006): Application of enzyme-linked immunosorbent assay (ELISA) for the study of reproduction in the Manila clam Ruditapes philippinarum (Mollusca: Bivalvia): II. Impacts of Perkinsus olseni on clam reproduction. Aquaculture, 251, 182-191.

Park, K. I, H. Tsutsumi, J. S. Hong, and K. S. Choi (2008): Pathology survey of the short-neck clam Ruditapes philippinarum occurring on sandy tidal flats along the coast of Ariake Bay, Kyushu, Japan. J. Invertebr. Pathol., 99, 212-219.

Sakai, K. and J. Onodera (2006): Epizootiological investigation on Perkinsus protozoan (Apicomplexa) infection in Manila clam Ruditapes philippinarum in Miyagi Prefecture, Japan. Miyagi Pref. Rep. Fish. Sci., 6, 77-81.

Shimokawa, J., T. Yoshinaga and K. Ogawa (2010): Experimental evaluation of the pathogenicity of Perkinsus olseni in juvenile Manila clams Ruditapes philippinarum. J. Invertebr. Pathol., 105, 347-351.

Takahashi, M, T. Yoshinaga, T. Waki, J. Shimokawa and K. Ogawa (2009): Development of a PCR-RFLP method for differentiation of Perkinsus olseni and P. honshuensis in the Manila clam Ruditapes philippinarum. Fish Pathol., 44, 185-189.

Villalba A., S. M. Casas, C. López, C. and M. J. Carballal (2005): Study of perkinsosis in the carpet shell clam Tapes decussatus in Galicia (NW Spain). II. Temporal pattern of disease dynamics and association with clam mortality. Dis. Aquat. Org., 65, 257-267.

Villalba, A., K. S. Reece, M. Camino Ordás, S. M. Casas and A. Figueras (2004) : Perkinsosis in mollusks: a review. Aquat. Living Resour., 17, 411-432. 